\title{
Corporate Social Responsibility in Hotel Industry: Empirical Analysis of Transitional Market
}

\author{
Petr Cech ${ }^{1}$, Irena Jindrichovska ${ }^{2}$, Jiri Neubauer ${ }^{3}$
}

\begin{abstract}
:
Using the non-parametric approach and data assembled by questionnaire survey among top and middle managers of hotels and hotel chains, the authors analyse management views on the importance of selected areas of Corporate Social Responsibility. The examined areas were the area of the relevant community, the economic, social and environmental areas.

The aim of this paper is to find what importance do managers attribute to individual activities in selected CSR areas in hotel industry and whether they are influenced by any characteristic features of hotels in question.

The research outcomes confirm the current state of development in the area CSR in transitional economy, which does not appreciate the complexity of current business world and concentrates predominantly on short and medium-term goals.

Among positive Czech specifics we can certainly count the detailed knowledge of local conditions in local environment and willingness of employees to provide additional services to their customers, which creates positive response from clients and contributes to their loyalty.
\end{abstract}

Keywords: Corporate Social Responsibility, Hotel Industry, Hospitality Management, Manager, Statistical Analysis

JEL Code: $M 14$

\footnotetext{
${ }^{1}$ Department of Management, The Institute of Hospitality Management in Prague, Czech Republic,cech@vsh.cz.

${ }^{2}$ School of Business Administration, Anglo-American university, Prague, Czech Republic, irena.jindrichovska@aauni.edu

${ }^{3}$ Department of Econometrics, University of Defence in Brno, Czech Republic, jiri.neubauer@unob.cz
} 


\section{Introduction}

Recently, we have witnessed a growing interest in Corporate Social Responsibility (hereinafter CSR), which is induced by both public sector - international organizations and governments and increasingly and by private sector companies themselves. European Union officials also emphasize that CSR can make major contribution to sustainable development while boosting Europe's competitiveness (EUR-Lex, 2011). The Corporate Social Responsibility is a voluntary integration of social and environmental considerations into daily business activities as well as into relationships with various corporate stakeholder's.

The first theoretical concept of the Corporate Social Responsibility originated in the second half of the 20th century in the USA. Since the 1990s, the European Union has also begun to deal with this issue. In July 2001, the European Commission issued the Green Paper "Promoting a European Corporate Social Responsibility Framework" (European Commission, 2001). This document brings the first general definition of the CSR and its objective was to launch a discussion on CSR and the possibilities for its promotion, measurement, and evaluation. In total it summarizes basic information as well as contacts in the field of the CSR and offers a more specific idea about the CSR itself, what its areas are, but it does not bring any specific rules. Subject matter of the CSR can be found in the recommendations of the International Labour Organization (ILO) and the Organization for Economic Cooperation and development (OECD).

CSR respects the interests of various stakeholders more or less connected with the firm-individual persons, groups or organizations that affect or are affected by the operation of the business. Nowadays in interconnected business world companies cannot afford to ignore stakeholders' interests. More and more consumers and customers use communication devices and social media to exchange information about the impact of various products on the environment, the health and wellbeing of people, families and communities and share their opinions on the quality of products and services which companies offer, but also on their social initiatives (Baldacchino et al., 2017; Suryanto et al., 2017).

Socially responsible entrepreneurs do not care only for traditional economic goals (profit maximization) but also try to comply with the social and environmental aspects of their activities. This is in practice manifested for example by (1) avoidance of corruption and ethical behaviour, (2) an effort to minimize negative impacts of their performance work on the environment, (3) respect of human work rights, (4) creation of work environment in which their employees can have a wellbalanced work and personal lives, (5) financial and nonfinancial support of the region in which the business operates (Rupeika-Apoga and Solovjova, 2017).

Corporate social responsibility contributes positively to society and thus it also has a whole range of contributions to the entrepreneurs and companies adopting it. These 
are often classified as non-financial gains and their impact is not immediately visible or perceivable. Some examples of the positive impacts of CSR can be the ability to attract high quality employees and to decrease their fluctuation, improving the reputation of the company, stimulation of innovation and increasing sales through increased loyalty of customers.

When considering the high competition in hotel industry there is also increasing importance of differentiation from the mainstream. An interest in the state of society or in the environment can then also become a competitive advantage in the social value area for the customer.

As it concerns the hotel managers, there are both positive and less positive opinions on CSR amongst them. However, it is possible to state that CSR should currently be an inherent part of development strategy for most hotels. Managers should understand that even though the results of CSR involvement are not immediate, good CSR creates a prerequisite for a positive image of a company in society and thus contributes to for positive opinions of the stakeholders about the said company.

Even between the companies in the hotel industry it is still necessary to strengthen the opinion that for long-term sustainable business success, which will cause an increase in the value of a company for its owners, it is not enough to only maximize short-term profits. Long-term goals are much more likely to be supported by longerterm socially responsible behaviour. Managers of successful companies in all areas, including the hotel industry, should understand that the basis of conduct of business is not only orienting the company towards economic growth but also towards the environmental and social aspects of their work.

It is logical that most of the new companies in hotel industry focus primarily on offering quality services, which are relevant to their function and which will fulfil the needs of their target groups -their customers. Managers of such companies are convinced that their company can fulfil the individual needs of customers better than other companies in the same business area. Top management of a company usually does not take its social responsibility immediately into consideration upon the company creation, because at that point it mostly concentrates on has other immediate and short-term goals.

More attention should be given to CSR by companies in the hotel industry in the next phase of their business life cycle, in the growth phase and during maturity. Then they begin to support employees in voluntary activities or provide financial support for example to charity organizations. If they understand that their contributions will bring with them positive societal response, they can themselves start actively influencing chosen area (Savina, 2016; Sharifz et al., 2018).

\section{Literature review}


Literature review sums up two approaches conceptual papers and empirical studies. One of the key summarising studies on the concept of corporate social responsibility, which proposes research framework and highlights future directions in the field of corporate social responsibility has been written by McWilliams, Siegel and Wright, 2006. The paper describes a variety of perspectives on CSR that are used to develop a framework for consideration of the strategic implications of CSR. Based on this framework, the authors propose an agenda for additional theoretical and empirical research on CSR based on review papers from the area. CSR is defined as a situation in which the company goes beyond compliance and engages in "actions that appear to further some social good, beyond the interests of the firm and that which is required by law" McWilliams and Siegel (2001). Fundamental concepts of CSR have been subsequently developed in many directions (Giannakopoulou et al., 2016).

The chief purpose of recent conceptual paper by Vallee (2005) is to assess the role and position of employees within the organization. The author reconciled the appearance of the term corporate social responsibility in Canadian regulation that corresponds to the new organizational modes of enterprises. Furthermore, he stresses that CSR has, of course, a moral or an ethical basis. As of the 1970s, enterprise strategies began to include dimensions that were not purely economic when these were likely to have an impact on their markets and on their image and, consequently, on the achievement of their economic goals.

The author stipulates that the economic goal of the enterprise did not change but the way of achieving the goal did. It started also taking into consideration the goals of involved stakeholders. CSR is a voluntary phenomenon, stemming from strategic choices made by corporate executives. In 1990, CSR started becoming an inherent part of part of corporate strategy. Also, the term corporate citizenship appeared (Vallee, 2005). The author acknowledges that in Quebec, it is in this sense that labour law can tribute to making employees true stakeholders in enterprises. Not just by allowing their interests to be "taken into account" by the enterprise's managers, but by making sure that their interests are carried by stable representatives, who have the capacity to negotiate and take action that can influence the whole orientations of the enterprise.

Misani (2010) in his paper explains detected convergence of CSR strategies of different enterprises converge and offers three explanations i.e. (1) herd behaviour, (2) institutional isomorphism and (3) strategic co-operations. These motives explain why many socially responsible firms appear to converge on a standard set of corporate social responsibility (CSR) practices instead of striving to differentiate themselves from rivals and achieve competitive advantage. The author uses critical analysis of industries with example of recent self-regulatory scheme launched by the steel industry. The paper also contributes to the debate on the financial benefits of CSR by arguing that in industries where the convergent type of CSR is dominant researchers should not expect above-average returns for socially responsible firms. 
The results show that social practices of firms are very often driven by pressures to conform, instead of pressures to perform.

Ivanova and Bikeeva (2016) provide theoretical analysis of evolution of researches of corporate social responsibility within the concept of the Russian enterprise and its restructuring. In their attempt to measure the level of CSR internal and external factors influencing development of corporate social responsibility of Russian organisations were determined. The authors claim that it is necessary to mention absence of connection between socially responsible behaviour of business in its economic activities. This belongs to shortages of existing methods for estimation of level of social responsibility. Social responsibility connected with functional activity of the enterprise is a multi-criteria task.

Authors suggest that the key steps in defining scientific novelty of the research consist of (1) specification of "business restructuring efficiency", (2) system of local criteria for estimation of business restructuring efficiency, (3) mathematical model of restructuring efficiency of enterprise, (4) comparative estimation and clustering of industrial enterprises according to the level of their social responsibility, and (5) technique of a complex estimation of business restructuring efficiency on the basis of holistic marketing and level of its social responsibility. Recent papers from the area of corporate social responsibility in hospitality industry concentrate on different aspects frequently on outward influence of CSR on customers and financial performance of CSR and inward influence-employee's behaviour and their motivation.

Discontinuation of CSR activity in hotels has been explored by Yaoqi Li, Shuji Fang, Tzung-Cheng, Chuan (2017). The study explored reaction of hotel customers in Chinese resorts. Collection of primary data was obtained from hotel customers. The authors have found that detrimental effect of discontinuation of CSR activity can be diminished if it considers how to reduce the image impact. The paper used experimental design. If a company intends to improve its image through having a short-term CSR and has no continued investment plan, our results suggest that starting the CSR practices may have the net result of damage to the company's image

Study by Quad Xiao et al. (2017) expresses different facets of corporate social responsibility in hotel industry in Korea using CSR dimensions proposed by Carroll's 1991 (philanthropic, ethical, legal, and economic). The importance of individual dimensions is explored on the background of different types of hotels.

Tian and Robertson (2017) started from the premise s that there is now considerable agreement that corporations significantly contribute to environmental degradation and investigated employees' voluntary pro-environmental behaviour on the background of corporate environmental engagement of their companies. The reason is that companies around the world are beginning to improve their environmental 
performance by influencing their employees to engage in voluntary proenvironmental behaviour. The authors analysed data from 183 supervisorsubordinate counterparts collected from large-and medium-sized casinos and hotels in Guangdong China and Macau and explored the effects of perceived corporate social responsibility on employees' voluntary pro-environment behaviour. The authors found that when employees perceive their organizations as socially and environmentally responsible, they are more likely to identify with their organization. These findings enhance understanding of the processes and conditions under which perceived CSR relates to workplace pro-environmental behaviour.

Kim et al. (2017) examined the links between Corporate Social Responsibility (CSR) and its internal consequences using the hotel employees' CSR perception namely Quality of Working Life, organizational citizenship, and job performance. Data sample was collected from hotel employees in upscale hotels in South Korea. Using regression analysis, the authors found that CSR perception by hotel employees positively influences their quality of working life, affective commitment, and organizational citizenship behaviour. Correspondingly an increasing number of prospective employees consider firms' social responsibility when they search for jobs. Among their considerations is the firm's social and environmental relationship with the surrounding community. This study found that the quality of hotel employees' working life positively influences their job performance.

In their research Haski-Leventhal et al. (2017) connect two dimensions of social responsibility: identity behaviour-to build patterns for classifying the social responsibility of employees and employers. Authors hereby block the examination of resemblance between employees and organizations with regard to social responsibility. Understanding of employee-employer congruence broadens the array of possibilities for achieving positive organizational outcomes based on CSR.

Theodoulidis et al. (2017) explore the links between financial performance (CFP) and CSR using two models that explicitly investigate the relationship between stakeholder management-the strategic stakeholder model and the intrinsic stakeholder commitment. Authors claim, that a number of comparative studies have been carried out to examine the CSR-CFP relationship in order to understand the reasons behind the mixed results. In this study the authors suggest that managers of tourism-related industries, and other tourism-related stakeholders at large, should be aware of the role of the social and environmental activities of firms, and how activities relating to employees, products, community, diversity and the environment create market value for the firm and other forms of value for society.

As it concerns previous Czech studies on CSR Pavlík and Belcik (2010) stated that CSR can be seen as an investment, which is supposed to bring more stability and prosperity to relevant company in long term. This gain, however, will not necessarily be financial. According to the Business Leaders Forum Czech Republic group, CSR is proposed in the inner environment of the company though a harmony between the 
company's stated rules and values and real practical application. In relation to the outward conduct of the company it is necessary that these rules and values are in harmony with the values of the society in which the business is conducted business. CSR stands on three basic pillars - economic, social and environmental.

Veber (2014) explains that CSR is not only as the fulfilment of legal obligations, but also responsible and voluntary conduct in:

- the economic area - preparation and follow up of business code;

- the social area - development of human capital within the company;

- the environmental perspective-improvement of the environmental profile;

- and relevant community involvement - good conduct as a neighbour and support for the region in which the company operates. Activities are now identified as corporate citizenship.

According to Skacelik (2010) a socially responsible company would be able to gain a number of benefits, most of them non-financial, when accepting the CSR concept. These benefits, in turn, stimulate growth in the financial area as well, as a responsible company can become more appealing to investors or customers and increasing sales and gaining better investment positions lead to financial gains. Most definitions of social responsibilities of a company require the management to act responsibly towards employees, customers, suppliers, local communities, the environment etc. In other words, this means that the company is expected to invest into activities which are beyond its legal obligations without them being clearly tied to the primary goal of the company.

It is necessary to realise that this primary goal of any company is to make profit for its owners and therefore even socially responsible activity must create revenue in the long run. Conducted research has proven that activities in the CSR areacan bring the following financial and non-financial benefits: (1) profit growth, (2) access to sufficient capital, (3) decreased costs, or increased efficiency, (4) better company image, (5) increased turnover and customer loyalty, (6) increased productivity and product quality, (7) increased ability to find and keep high-quality employees, (8) decreased risks, decreased costs of risk management, (9) easier position in keeping up with competition and facing market demands.

A study conducted by Čech and Neubauer (2010), assessed attitudes towards using a good name of a company in the area of social responsibility and pointed out, that what is the most important for long-term growth is the creation of a strong brand, acquisition of loyal customers (stakeholders) and generating innovations of products and services. This study also concluded that the biggest accent in terms of social responsibility of hotels lies in the economic area and the lowest remains on the environmental area. The importance of defining and employing relevant CSR strategy based on gaining excellent reputation in the area of social responsibility 
based onparticular location, hotel size and use of ethical code was also highlighted as important.

The follow-up study by Veber and Srpova (2012) assert that entrepreneurs and companies in the Czech Republic should not understand their social responsibility purely in terms of abiding by the law and pursuing company philanthropy. While direct financial or material support is the most common pronouncement of social engagement in the Czech Republic. Although, there are many other ways in which a company can help the community. For example (1) through its knowledge, skills and experience, (2) renting out corporate space, (3) providing know-how, (4) providing consultancy, (5) enticing employee volunteering, (6) donating the company's own products or resources, (7) providing services, (8) providing education and training, (9) announcing public tenders and prices.

Jindrichovska and Kohout (2016) used the BSC methodology applied on a sample of small, medium and large Czech hotels in rural areas and big cities. The study was conducted using questionnaire survey and revealed that that Czech hotels are mostly concentrating on day to day issues and do not devote too much attention to management of their long-term sustainability. They accent mainly short-term perspective and deal principally with customers and financials, ignoring employees and innovations, which seems to be rather unbalanced approachignoring ling term CSR aspects. Nevertheless, this may not be universally true in case of big hotels and hotel chains.

This presented study broadens the perspective and analyses management views on the importance of selected four areas of Corporate Social Responsibility in hospitality industry in the Czech Republic and Slovakia. It links to previous Czech studies of hospitality industry.

\section{Data and Method}

In line with Veber (2014) this paper focuses on four areas related to CSR: (1) economic, (2) social, (3) environmental and that of the (4) relevant community. In this research we did not concentrate on legal aspects, as managers are required to act in line with all relevant laws and therefore their conduct in this area cannot be classified as voluntary behaviour.

Authors have conducted a questionnaire survey with the goal of mapping the attitudes of managers of hotels and hotel chains towards the CSR issues in hotel industry. To fulfil this goal, we have set the following research question: What importance do hotel managers assign to relevant activities in each the economic, social, environmental and community areas.

The base group for this research included all managers (top or mid-level) of independent hotels or hotels which are part of hotel chains in the Czech Republic 
and Slovakia. Inquirers were appointed to collect data through a questionnaire given to managers of hotels and hotel chains. Of the total number of 650 questionnaires, 319 were filled in and returned by respondents. These respondents are thus the base group for this research. The rate of return of the questionnaires was $49.1 \%$. Tables capture the evaluation ofindividual activities were prepared on the basis of the collected data and the answers were also graphically depicted using boxplots.

The authors have formulated and tested hypotheses relating to the influence of factors such as the individual unit or its presence as a part of a chain, the size of the hotel, the hotel class (star rating), the managerial position and the region in which the hotel is located on the importance attributed to the activities in the economic, social, environmental and community area.

The importance of particular activities in the analysed areas was assessed through the Friedman test. The null hypotheses of this test were the statement that all the activities hold the same importance. In the case of thenull hypothesis being rejected, a multiple comparison method was applied (Pairwise post-hoc test for multiple comparison - Nemenyi test). More on this method can be found in Demsar (2006). To verify the dependency of the answers on factors such as the existence of an ethical code, hotel class, hotel size, managerial position of the respondent and location, either Wilcoxon or Kruslal-Wallis test was used, depending on the factor examined. All statistical tests were calculated at the five per cent significance level (Andel 2003; Devore 2012).

\section{Results and Discussion}

Table 1 contains the evaluation of activities in the area of relevant community involvement based on a set order according to importance - (A) Financial support for local culture and social traditions, (B) Offering information about local customs and traditions, (C) Preparation of local foods, (D) Offering information about local sights and natural curiosities. The scale used placed 1 as the least important and 4 as the most important activity. The table contains the median ranking, the order is based on average and on median.

Table 1. Evaluation of the importance of activities in the relevant community involvement area

\begin{tabular}{|l|l|l|l|l|}
\hline Activity & average & median & $\begin{array}{l}\text { ranking based } \\
\text { on average } \\
\text { value }\end{array}$ & $\begin{array}{l}\text { ranking based } \\
\text { on median }\end{array}$ \\
\hline A & 2.224 & 2 & 4 & 4 \\
\hline B & 2.485 & 3 & 3 & 2 \\
\hline C & 2.567 & 3 & 2 & 2 \\
\hline D & 2.728 & 3 & 1 & 2 \\
\hline
\end{tabular}

Source: Own survey. 
The data in Table 1 tells us that the respondents gave least importance to the financial support for local culture and social traditions. The other activities were assigned a relatively similar importance. Respondents tend to favour those activities which will in turn bring them higher profit and they are less likely to prefer an increase in expenses - providing financial support. Figure 1 Boxplots showing the evaluation of activities in the area of relevant community involvement

Figure 1. Boxplots

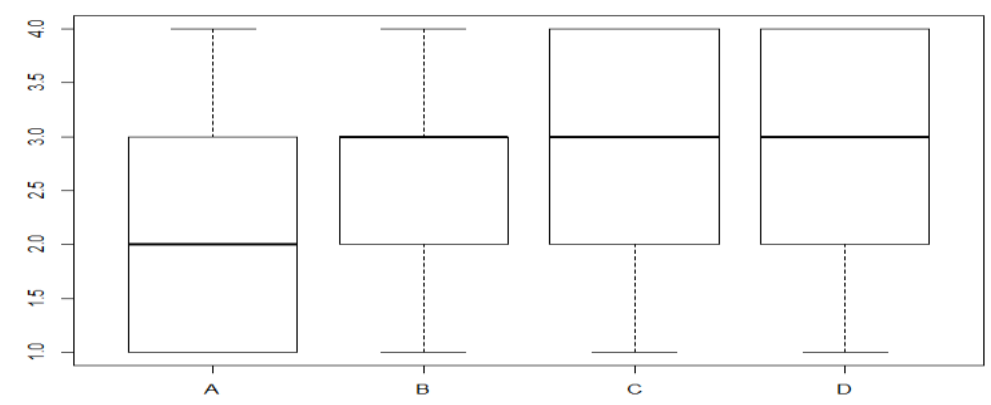

Source: Own survey.

Legend: (A) Financial support for local culture and social traditions, (B) Offering information about local customs and traditions, (C) Preparation of local foods, (D) Offering information about local sights and natural curiosities.

The boxplots in Figure 1 show the lowest and highest value, the median, lower and upper quartile of the answers of respondents to the evaluation of importance of activities in the area of relevant community involvement. The authors further tested the hypothesis that all activities in the area of relevant community involvement are valued at the same importance. A post-hoc analysis was carried out on the findings which differed from each other. The Friedman test (null distribution has the value of 21.289, p-value $=9.168 \cdot 10^{-5}$ ) proved a significant difference, individual activities in the area of relevant community involvement were not evaluated the same by the respondents. A more detailed analysis was performed using multiple comparison methods, where one examines if individual sets of activities are evaluated the same or not, as shown in Table 2.

Table 2. 2P-values of pairwise post-hoc test for multiple comparison - Nemenyi test, Bonferroni approach - activities in the relevant community involvement area

\begin{tabular}{|l|l|l|l|}
\hline & A & B & C \\
\hline B & $\mathbf{0 , 0 2 2 0 0}$ & - & - \\
\hline C & $\mathbf{0 , 0 0 0 0 0}$ & 1.00000 & - \\
\hline D & $\mathbf{0 . 0 0 0 0 0}$ & $\mathbf{0 . 0 0 0 2 8}$ & 0,28021 \\
\hline
\end{tabular}

Source: Own survey. 
Activity A (Financial support for local culture and social traditions) is considered the least important (which is apparent from Graph 1 and the test results). Furthermore, the test proved that activity B (Offering information about local customs and traditions) is considered less important than activity D (Offering information about local sights and natural curiosities of the place). A difference between activity $\mathrm{C}$ (Preparation of local foods) and D (Offering information about local sights and natural curiosities of the place) was not proven.

Table 3 contains the evaluation of activities in the economic area of CSR based on an order set according to importance - (A) Avoiding corruption and ethical behaviour, (B) Adoption and exercise of principles of good management, (C) Trustworthy, transparent business transactions and provision of information about the company, (D) Long-term building of relationships with customers and suppliers, (E) Monitoring the interests of main owners and their awareness, (F) Respect and protection of intellectual property, (G) Innovation and continuous development of the hotel/hotel chain, $(\mathrm{H})$ Respecting the rules of Fairtradecompetition. A scale was where 1 corresponds to least important and 8 to most important activity. The Table contains the median ranking, the order is based on average and on median value.

Table 3. Evaluation of the importance of activities in the economic area

\begin{tabular}{|l|l|l|l|l|}
\hline Activity & average & median & $\begin{array}{l}\text { ranking based } \\
\text { on average } \\
\text { value }\end{array}$ & $\begin{array}{l}\text { ranking based } \\
\text { on median } \\
\text { value }\end{array}$ \\
\hline A & 4.735 & 5 & 3.0 & 3.5 \\
\hline B & 4.569 & 5 & 4.5 & 3.5 \\
\hline C & 4.569 & 4 & 4.5 & 6.0 \\
\hline D & 5.621 & 6 & 1.0 & 1.5 \\
\hline E & 4.158 & 4 & 6.0 & 6.0 \\
\hline F & 3.194 & 3 & 8.0 & 8.0 \\
\hline G & 5.340 & 6 & 2.0 & 1.5 \\
\hline H & 3.889 & 4 & 7.0 & 6.0 \\
\hline
\end{tabular}

Source: Own survey.

From the data presented in Table 3 it is evident that respondents assigned the highest importance to option (D) building of long-term relationships with customers and suppliers, followed by option $(\mathrm{G})$ innovation and sustainable development of the hotel/hotel chain. The lowest importance was assigned to option (F) respecting and protection of intellectual propertyand option $(\mathrm{H})$ respecting of the rules of fair trade competition. However, creation of development strategy would be impossible without good relationship with customers and innovation. On the one hand an opinion has emerged that the protection of intellectual property will have the least positive impact on the economic results of the hotel. Figure 2 shows the boxplots of the evaluation of the activities in the economic area. 
Figure 2. Boxplots showing the evaluation of the activities in the economic area

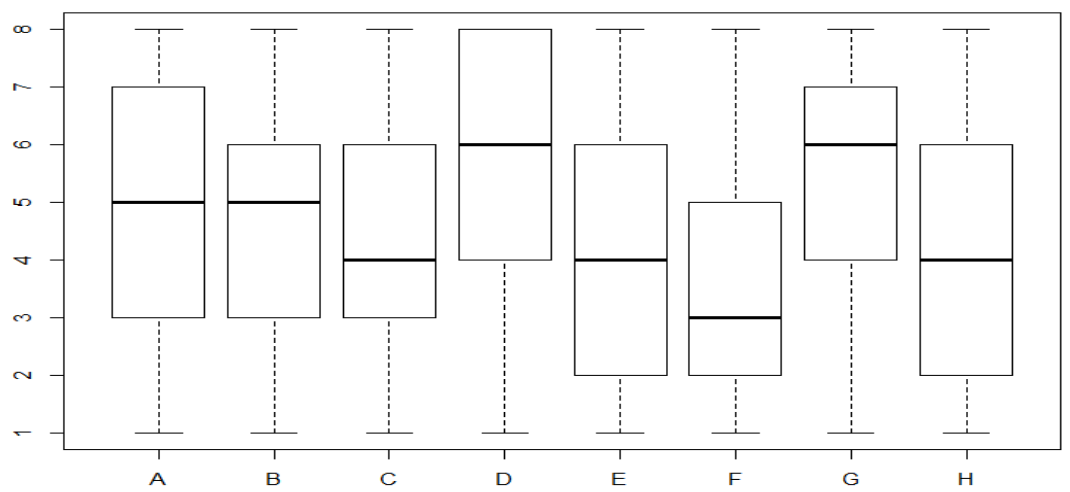

Source: Own survey.

Notes: (A) Avoiding corruption and ethical behaviour, (B) Adoption and exercise of principles of good management, (C) Trustworthy, transparent business transactions and provision of information about the company, (D) Long-term building of relationships with customers and suppliers, (E) Monitoring the interests of main owners and their awareness, $(F)$ Respect and protection of intellectual property, $(G)$ Innovation and continuous development of the hotel/hotel chain, $(H)$ Respecting the rules of fair trade competition.

A Friedman test (null distribution value 177.35 , p-value $<2.2 \cdot 10^{-16}$ ) proved a significant difference. It is therefore safe to state that the individual activities in the economic area were not evaluated as same by the respondents. The results of multiple comparison testing are captured in Table 4.

Table 4. Values of pairwise post-hoc test for multiple comparison - Nemenyi test, Bonferroni approach-activities in the economic area

\begin{tabular}{|l|l|l|l|l|l|l|l|}
\hline & $\mathrm{A}$ & $\mathrm{B}$ & $\mathrm{C}$ & $\mathrm{D}$ & $\mathrm{E}$ & $\mathrm{F}$ & $\mathrm{G}$ \\
\hline $\mathrm{B}$ & 1.00000 & - & - & - & - & - & - \\
\hline $\mathrm{C}$ & 1.00000 & 1.00000 & - & - & - & - & - \\
\hline $\mathrm{D}$ & $\mathbf{0 . 0 0 0 0 0}$ & $\mathbf{0 . 0 0 0 0 0}$ & $\mathbf{0 . 0 0 0 1 3}$ & - & - & - & - \\
\hline $\mathrm{E}$ & 1.00000 & 1.00000 & 1.00000 & $\mathbf{0 . 0 0 0 1 7}$ & - & - & - \\
\hline $\mathrm{F}$ & 1.00000 & 1.00000 & 1.00000 & $\mathbf{0 . 0 0 0 0 0}$ & 0.96310 & - & - \\
\hline $\mathrm{G}$ & $\mathbf{0 . 0 0 0 0 0}$ & $\mathbf{0 . 0 0 0 0 0}$ & $\mathbf{0 . 0 0 0 0 0}$ & 1.00000 & $\mathbf{0 . 0 0 0 0 0}$ & $\mathbf{0 . 0 0 0 0 0}$ & - \\
\hline $\mathrm{H}$ & 1.00000 & 1.00000 & 1.00000 & 0.22824 & 1.00000 & $\mathbf{0 . 0 0 1 5 3}$ & $\mathbf{0 . 0 0 0 2 9}$ \\
\hline
\end{tabular}

Source: Own survey.

Activities A (Avoiding corruption and ethical behaviour), B (Adoption and exercise of principles of good management) and $\mathrm{C}$ (Trustworthy, transparent business transactions and provision of information about the company) were claimed to be less important by the respondents than D (Long-term building of relationships with customers and suppliers) and $\mathrm{G}$ (Innovation and continuous development of the hotel/hotel chain). Activity D (Long-term building of relationships with customers 
and suppliers) was claimed to be more important than E (Monitoring the interests of main owners and their awareness) and F (Respect and protection of intellectual property). Activity $\mathrm{G}$ (Innovation and continuous development of the hotel/hotel chain) was evaluated as more important than $\mathrm{E}$ (Monitoring the interests of main owners and their awareness). Activity F (Respect and protection of intellectual property) is seen as less important than $\mathrm{G}$ (Innovation and continuous development of the hotel/hotel chain), $\mathrm{H}$ (Respecting the rules of fair trade competition) and $\mathrm{E}$ (Monitoring the interests of main owners and their awareness). Activity $\mathrm{G}$ was more important than $\mathrm{H}$ (Respecting the rules of fair trade competition).

Table 5 shows the evaluation of activities in the social area of CSR based on the set order according to importance - (A) Creating conditions for raising qualifications and carrier growth of employees, (B) Elimination of discriminative acts in the workplace, (C) Fair reward system, (D) Respect for a social dialogue while preserving economic stability and growth, (E) Respect for principles of equal work opportunities, (F) Fight against mobbing and sexual harassment, (G) Emphasis on humanisation of work, care for the health and safety of employees, $(\mathrm{H})$ Creating a healthy company culture, (I) Evaluating the social impact of managerial decisions, (J) Adaptation of working conditions for the work and problem-free stay of persons with health disabilities, (K) Company volunteering, (L) Organised leisure time activities - e.g. Teambuilding. The table contains the median ranking, the order is based on average and on median value.

Table 5. Evaluation of the importance of activities in the social area

\begin{tabular}{|l|l|l|l|l|}
\hline Activity & average & median & $\begin{array}{l}\text { ranking based } \\
\text { on average } \\
\text { value }\end{array}$ & $\begin{array}{l}\text { ranking based } \\
\text { on median } \\
\text { value }\end{array}$ \\
\hline A & 8.230 & 9 & 1 & 1.5 \\
\hline B & 6.883 & 8 & 6 & 3.5 \\
\hline C & 8.066 & 9 & 2 & 1.5 \\
\hline D & 5.798 & 6 & 8 & 7.5 \\
\hline E & 6.922 & 7 & 5 & 5.5 \\
\hline F & 5.272 & 5 & 11 & 10.0 \\
\hline G & 7.198 & 7 & 4 & 5.5 \\
\hline H & 7.852 & 8 & 3 & 3.5 \\
\hline I & 5.864 & 5 & 7 & 10.0 \\
\hline J & 5.778 & 5 & 9 & 10.0 \\
\hline K & 4.222 & 2 & 12 & 12.0 \\
\hline L & 5.642 & 6 & 10 & 7.5 \\
\hline
\end{tabular}

Source: Own survey.

From the data presented in Table 5 it is clear, that respondents assigned highest importance to the creation of conditions for raising qualifications and carrier growth of employees (A) and furthermore to a fair rewards system (C). Lowest importance was assigned to company volunteering $(\mathrm{K})$ and the fight against mobbing and sexual harassment $(\mathrm{F})$. Managers tend to give a lot of focus to the quality and rewarding of 
human resources which is generally true even is a company which does not engage in CSR. This fact is also supported by the low emphasis placed on company volunteering. The low perceived importance of the fight against mobbing and sexual harassment corresponds with the opinions of wider society regarding this problematic and other research in the area.

Figure 3. Boxplots showing the evaluation of the activities in the social area

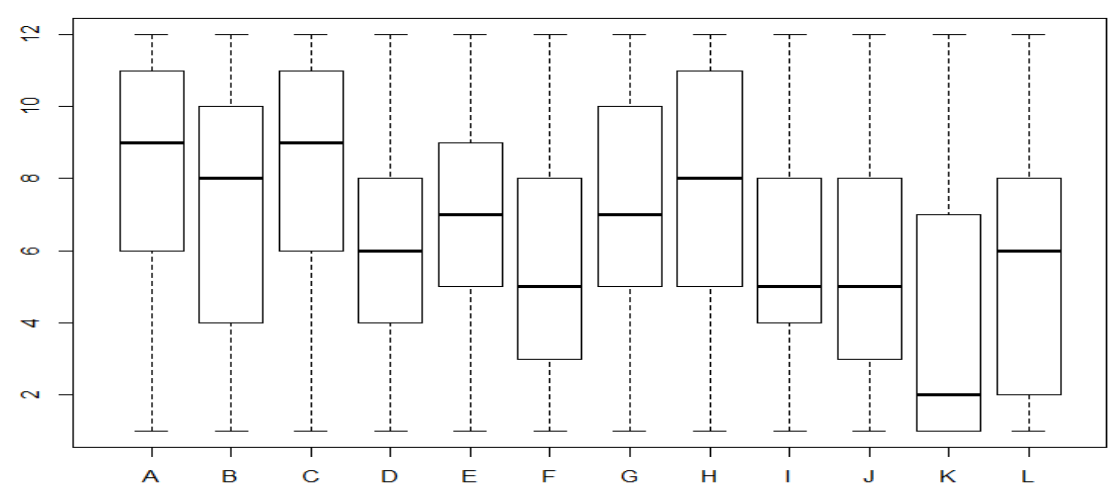

Source: Own survey.

Figure 3 shows the boxplots for the evaluation of activities in the social area. A Friedman test was used to test the hypothesis that all the activities in the social area were evaluated as same and a post-hoc analysis was executed to find out which statements differ in value. The Friedman test (null distribution value 226.82, p-value $<2.2 \cdot 10^{-16}$ ) confirmed a statistically significant difference. It is therefore impossible to ascertain that the various activities were valued the same by the respondents. For a more detailed analysis (multiple comparison) see Table 6.

Table 6. 6P-values of pairwise post-hoc test for multiple comparison - Nemenyi test, Bonferroni approach-activities in the social area

\begin{tabular}{|l|l|l|l|l|l|l|l|l|l|l|l|}
\hline & A & B & C & D & E & F & G & H & I & J & K \\
\hline B & 1 & - & - & - & - & - & - & - & - & - & - \\
\hline C & 1 & 0,240 & - & - & - & - & - & - & - & - & - \\
\hline D & $\mathbf{0}$ & 1 & $\mathbf{0}$ & - & - & - & - & - & - & - & - \\
\hline E & 1 & 1 & 1 & 0,517 & - & - & - & - & - & - & - \\
\hline F & $\mathbf{0}$ & 1 & $\mathbf{0}$ & 1 & 0,123 & - & - & - & - & - & - \\
\hline G & 1 & 0,723 & 1 & $\mathbf{0}$ & 1 & $\mathbf{0}$ & - & - & - & - & - \\
\hline H & 1 & $\mathbf{0}$ & 1 & $\mathbf{0}$ & $\mathbf{0 , 0 4 5}$ & $\mathbf{0}$ & 1 & - & - & - & - \\
\hline I & 1 & 1 & 1 & 1 & 1 & 1 & 1 & $\mathbf{0 , 0 0 1}$ & - & - & - \\
\hline J & 1 & 1 & 1 & 1 & 1 & 0,694 & 1 & $\mathbf{0 , 0 0 6}$ & 1 & - & - \\
\hline K & $\mathbf{0}$ & 1 & $\mathbf{0}$ & 1 & $\mathbf{0 , 0 3 8}$ & 1 & $\mathbf{0}$ & $\mathbf{0}$ & 0,923 & 0,246 & - \\
\hline L & 1 & 1 & 1 & 0,179 & 1 & 0,38 & 1 & 0,145 & 1 & 1 & $\mathbf{0 , 0 1 1}$ \\
\hline
\end{tabular}

Source: Own survey. 
From the presented data we can conclude that differences in the evaluation of the activities in the social area can be seen in pairs as stated: A-D, A-F, A-K, B-H, C-D, C-F, C-K, D-G, D-H, E-H, E-K, F-G, F-H, G-K, H-I, H-J, H-K, K-L.

"Creating the conditions for raising qualifications and carrier growth of employees" was evaluated differently from "Respecting a social dialogue while preserving economic stability and growth", "Fight against mobbing and sexual harassment" and "Company volunteering".

"Elimination of discrimination in the workplace" was evaluated differently from "Creating a healthy company culture". "Fair reward system" was given different value by the respondents than "Respecting a social dialogue while preserving economic stability and growth", "Fight against mobbing and sexual harassment" and "Company volunteering". "Respecting a social dialogue while preserving economic stability and growth" was evaluated differently than "Emphasis on the humanisation of work and care for the health and safety of employees" and "Creating a healthy company culture".

There were also differences between "Respecting the principles of equal job opportunities" and "Creating a healthy company culture" and "Company volunteering". "Fight against mobbing and sexual harassment" was evaluated differently from "Emphasis on the humanisation of work and care for the health and safety of employees" and "Creating a healthy company culture". "Emphasis on humanisation of work and care for the health and safety of employees" was given different value than "Company volunteering". "Creating a healthy company culture" was evaluated differently than "Evaluating the social impact of managerial decisions", "Adaptation of working conditions for the work and problem-free stay of persons with health disabilities" and "Company volunteering". And lastly, "Company volunteering was given different value than "Organised leisure time activities".

Table 7 contains the evaluation of activities in the environmental area of CSR based on an order according to importance - (A) Realisation of business operations in accordance with the tourism development plan while conserving natural and cultural inheritance, (B) Environmentally friendly waste disposal, (C) Preservation of natural resources through decreased water usage, (D) Use of solar panels, central light switches and other measures for conserving electricity, (E) Use of intelligent systems of measuring and regulation for buildings, $(\mathrm{F})$ Choice of materials, paints and other components without or with low amounts of volatile organic substances, (G) Use of environmentally friendly cleaning supplies, (H) Decreased use of chemicals of all kinds, (I) Leading customers towards environmentally friendly behaviour (decreased water use etc.), (J) Use of organic products such as tea and coffee (e.g. Fair Trade). A scale was used in which 1 is the least important and 10 is the most important activity. The table contains the median ranking, the order is based on average and on median value. 
Table 7. Evaluation of the importance of activities in the environmental area

\begin{tabular}{|c|c|c|c|c|}
\hline Axtivity & average & median & $\begin{array}{l}\text { rating based on } \\
\text { average value }\end{array}$ & $\begin{array}{lr}\text { rating } & \begin{array}{r}\text { based } \\
\text { on } \\
\text { value }\end{array} \\
\text { median } \\
\end{array}$ \\
\hline $\mathrm{A}$ & 5.399 & 5 & 6 & 7.5 \\
\hline $\mathrm{B}$ & 6.815 & 8 & 1 & 1.0 \\
\hline $\mathrm{C}$ & 6.122 & 6 & 2 & 4.0 \\
\hline $\mathrm{D}$ & 5.390 & 6 & 7 & 4.0 \\
\hline $\mathrm{E}$ & 5.949 & 6 & 3 & 4.0 \\
\hline $\mathrm{F}$ & 4.555 & 4 & 9 & 9.5 \\
\hline $\mathrm{G}$ & 5.613 & 6 & 5 & 4.0 \\
\hline $\mathrm{H}$ & 5.110 & 5 & 8 & 7.5 \\
\hline I & 5.622 & 6 & 4 & 4.0 \\
\hline $\mathrm{J}$ & 4.492 & 4 & 10 & 9.5 \\
\hline
\end{tabular}

Source: Own survey.

From the data presented in Table 7 and Figure 4 we can conclude that respondents assigned highest importance to Environmentally friendly waste disposal (B) followed by Preservation of natural resources through decreased water usage (C). On the other hand, lowest priority was given to the Use of organic products such as tea and coffee $(\mathrm{J})$ and then Choice of materials, paints and other components without or with low amounts of volatile organic substances $(F)$. It can be said that the opinions of respondents in this area were formed mainly by the need to follow relevant laws and regulations and furthermore the need to lower the costs of the economic operation of the hotel.

Figure 4. Boxplots showing the evaluation of activities in the environmental area

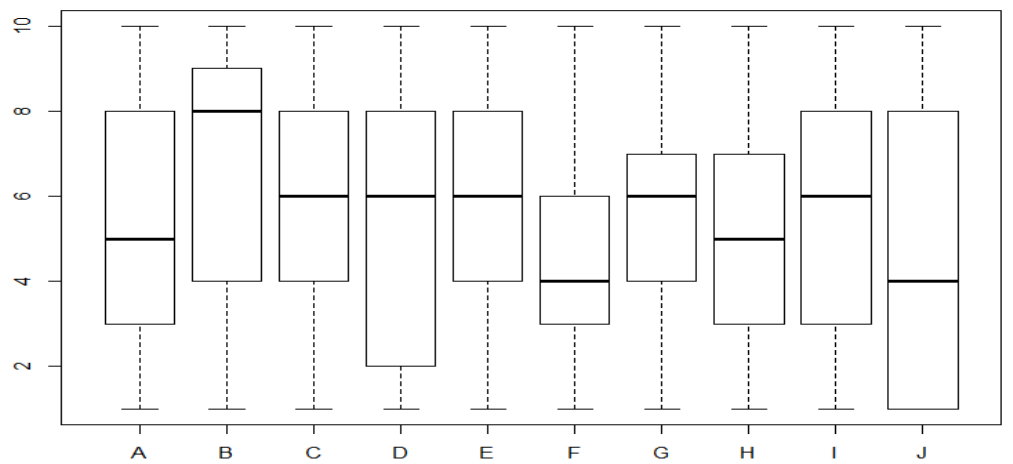

Source: Own survey.

Similarly, to the previous sections, a hypothesis was tested that all activities in the environmental area are valued the same and a post-hoc analysis was executed in order to find out which answers differ. The Friedman test (null distribution value 
120.8, p-value $<2.2 \cdot 10^{-16}$ ) confirmed a significant difference which means that individual activities in the environmental area were not evaluated the same. From the data presented in Table 8 we can see that a difference can be observed in the pairs AB, A-E, A-G, A-I, B-F, D-I, F-G, F-I.

"Realisation of business operations in accordance with the tourism development plan while conserving natural and cultural inheritance" was evaluated differently from "Environmentally friendly waste disposal", "Use of intelligent systems of measuring and regulation for buildings", "Use of environmentally friendly cleaning supplies" and "Leading customers towards environmentally friendly behaviour (decreased water uses etc.)".

"Environmentally friendly waste disposal" was given different value than "Choice of materials, paints and other components without or with low amounts of volatile organic substances". Activity "Use of solar panels, central light switches and other measures for conserving electricity" was evaluated differently from "Leading customers towards environmentally friendly behaviour (decreased water uses etc.)". Also, "Choice of materials, paints and other components without or with low amounts of volatile organic substances" was given different value than "Use of environmentally friendly cleaning supplies" and "Leading customers towards environmentally friendly behaviour (decreased water uses etc.)".

Table 8. P-values of pairwise post-hoc test for multiple comparison - Nemenyi test, Bonferroni approach-activities in the environmental area

\begin{tabular}{|l|l|l|l|l|l|l|l|l|l|}
\hline & A & B & C & D & E & F & G & H & I \\
\hline B & $\mathbf{0}$ & - & - & - & - & - & - & - & - \\
\hline C & 0,254 & 1 & - & - & - & - & - & - & - \\
\hline D & 1 & 1 & 1 & - & - & - & - & - & - \\
\hline E & $\mathbf{0 , 0 0 9}$ & 1 & 1 & 1 & - & - & - & - & - \\
\hline F & 1 & $\mathbf{0 , 0 0 3}$ & 1 & 1 & 0,101 & - & - & - & - \\
\hline G & $\mathbf{0 , 0 0 2}$ & 1 & 1 & 1 & 1 & $\mathbf{0 , 0 2 6}$ & - & - & - \\
\hline H & 0,187 & 1 & 1 & 1 & 1 & 1 & 1 & - & - \\
\hline I & $\mathbf{0}$ & 1 & 1 & $\mathbf{0 , 0 3 0}$ & 1 & $\mathbf{0}$ & 1 & 1 & - \\
\hline J & 1 & 1 & 1 & 1 & 1 & 1 & 1 & 1 & 1 \\
\hline
\end{tabular}

Source: Own survey.

The authors of this article furthermore formulated and tested hypotheses concerning the influence of the existence of an ethical code, the independence of a hotel or its belonging to a chain, the size of the hotel, the hotel class (star rating), the managerial position and the region in which the hotel is located on the importance attributed to the activities of the social responsibility spectrum. The dependency of the answers on these variables was assessed either by the Wilcoxon test (the factor has only two possible values, as in the example of the existence of an ethical code: yes, no) or with the use of Kruslal-Wallis test (factor has multiple possible values, e.g. hotel class - star rating). The test results (p-values of the tests) are presented in Tables 9 to 
12. P-values lower than the significance level of 0.05 are written in bold, pointing to a statistically significant influence of the said factor on the answers.

Table 9. P-values of the Wilcoxon* and Kruslal-Wallis** test for the influence on the evaluation of the relevant community involvement area

\begin{tabular}{|l|l|l|l|l|l|l|}
\hline Activity & $\begin{array}{l}\text { Existence } \\
\text { of an } \\
\text { ethical } \\
\text { code* }\end{array}$ & $\begin{array}{l}\text { Hotel/hotel } \\
\text { chain* }\end{array}$ & $\begin{array}{l}\text { Hotel } \\
\text { class** }\end{array}$ & $\begin{array}{l}\text { Hotel } \\
\text { size** }\end{array}$ & $\begin{array}{l}\text { Managerial } \\
\text { position* }\end{array}$ & Region* \\
\hline $\begin{array}{l}\text { 1A) Financial } \\
\text { support for } \\
\text { local culture } \\
\text { and social } \\
\text { traditions }\end{array}$ & 0,9639 & 0,21167 & 0,4454 & 0,44063 & 0,08165 & 0,11503 \\
\hline $\begin{array}{l}\text { 1B) Offering } \\
\text { information } \\
\text { about local } \\
\text { customs and } \\
\text { traditions }\end{array}$ & 0,16276 & 0,96545 & 0,13375 & 0,82551 & $\mathbf{0 , 0 2 0 4 7}$ & 0,1486 \\
\hline $\begin{array}{l}\text { 1C) } \\
\text { Preparation of } \\
\text { local foods }\end{array}$ & 0,07417 & 0,09054 & $\mathbf{0 , 0 2 5 1 1}$ & $\mathbf{0 , 0 4 9 9 3}$ & 0,0584 & 0,95046 \\
\hline $\begin{array}{l}\text { 1D) Offering } \\
\text { information } \\
\text { about local } \\
\text { sights and } \\
\text { natural } \\
\text { curiosities }\end{array}$ & 0,27265 & 0,51998 & 0,17685 & 0,14476 & 0,11775 & 0,46049 \\
\hline
\end{tabular}

The only significant influence was that of hotel class on the activity "Preparation of local foods". No other significant dependency could be proven in the area of relevant community involvement. Conditioned medians of the individual factors allowed for comparison for example of the star rating hotel has, that is, which star rating has the highest or lowest median. Multiple comparison methods, that is, post-hoc tests, were used to identify this, much like in the previous section of the article. The activity "Preparation of local foods" is given the highest priority by the managers of five-star hotels (the median for five-star hotels is 4 - the highest value; hotels with 1 star and with 4 stars have a median of 2.5 , hotels with 2 and 3 stars have a median of 2).

A dependency was found when evaluating the importance of activity "Preparation of local foods". A higher importance is given to it by managers of mid-sized hotels (the median for a mid-sized hotel is 3,2 for small and large hotels). The influence of managerial position of the respondent is tangible only in the evaluation of the importance of activity "Offering information about local customs and traditions" in the area of relevant community involvement. More importance is given to this activity by managers in the mid-level positions (median for top managers is 2 , for 
mid-level managers it is 3). A dependency on the location of the hotel in the Czech Republic or Slovakia could not be proven.

Table 10. P-values of the Wilcoxon* and Kruslal-Wallis** test for the influence onthe evaluation of the economic area

\begin{tabular}{|c|c|c|c|c|c|c|}
\hline Activity & $\begin{array}{l}\text { Existence } \\
\text { of an } \\
\text { ethical } \\
\text { code* }\end{array}$ & $\begin{array}{l}\text { Hotel/hotel } \\
\text { chain* }\end{array}$ & $\begin{array}{l}\text { Hotel } \\
\text { class** }\end{array}$ & $\begin{array}{l}\text { Hotel } \\
\text { size** }\end{array}$ & $\begin{array}{l}\text { Managerial } \\
\text { position* }\end{array}$ & Region* \\
\hline $\begin{array}{l}\text { 2A) } \\
\text { Avoidin } \\
\mathrm{g} \\
\text { corruptio } \\
\mathrm{n} \text { and } \\
\text { ethical } \\
\text { behaviour }\end{array}$ & $\mathbf{0 , 0 2 9 1 3}$ & 0,36957 & 0,60345 & 0,10989 & 0,20339 & $\mathbf{0 , 0 2 7 0 7}$ \\
\hline $\begin{array}{l}\text { 2B) } \\
\text { Adoption } \\
\text { and exercise } \\
\text { of principles } \\
\text { of good } \\
\text { management }\end{array}$ & 0,04213 & 0,11517 & 0,731 & 0,43103 & 0,83905 & 0,08496 \\
\hline $\begin{array}{l}2 \mathrm{C}) \\
\text { Trustworthy, } \\
\text { transparent } \\
\text { business } \\
\text { transactions } \\
\text { and } \\
\text { provision of } \\
\text { information } \\
\text { about the } \\
\text { company }\end{array}$ & 0,03045 & 0,63787 & 0,1906 & 0,18695 & 0,10555 & 0,06193 \\
\hline $\begin{array}{l}\text { 2D) Long- } \\
\text { term building } \\
\text { of } \\
\text { relationships } \\
\text { with } \\
\text { customers } \\
\text { and suppliers }\end{array}$ & 0,08605 & 0,02288 & 0,55473 & 0,00562 & 0,25153 & 0,0348 \\
\hline $\begin{array}{l}\text { 2E) } \\
\text { Monitori } \\
\text { ng the } \\
\text { interests } \\
\text { of main } \\
\text { owners } \\
\text { and their } \\
\text { awarenes } \\
\text { s }\end{array}$ & 0,79174 & 0,08813 & 0,31341 & 0,62035 & 0,7373 & 0,14471 \\
\hline
\end{tabular}




\begin{tabular}{|c|c|c|c|c|c|c|}
\hline $\begin{array}{l}\text { 2F) Respect } \\
\text { and } \\
\text { protectio } \\
\mathrm{n} \quad \text { of } \\
\text { intellect } \\
\text { ual } \\
\text { property }\end{array}$ & 0,89064 & 0,5073 & 0,95206 & 0,98936 & 0,08636 & 0,00003 \\
\hline $\begin{array}{l}2 \mathrm{G}) \\
\text { Innovation } \\
\text { and } \\
\text { continuous } \\
\text { development } \\
\text { of the } \\
\text { hotel/hotel } \\
\text { chain }\end{array}$ & 0,09725 & 0,90295 & 0,90177 & 0,98681 & 0,50183 & 0,17623 \\
\hline $\begin{array}{l}\text { 2H) } \\
\text { Respecti } \\
\text { ng the } \\
\text { rules of } \\
\text { fair trade } \\
\text { competit } \\
\text { ion }\end{array}$ & 0,16845 & 0,29218 & 0,21096 & 0,3475 & 0,43345 & 0,0139 \\
\hline
\end{tabular}

The existence of an ethical code of a hotel/hotel chain has an influence on the practice of three activities in the economic area: $2 \mathrm{~A}, 2 \mathrm{~B}$ and $2 \mathrm{C}$. The independency of a hotel or its belonging to a chain only had an impact on the evaluation of the activity "Long-term building of relationships with customers and suppliers". There were no provable influences of the hotel class on these variables.

Activities "Avoiding corruption and ethical behaviour" and "Trustworthy, transparent business transactions and provision of information about the company" were given more importance by managers of hotels with an ethical code (for both activities the median for hotels with an ethical code was 5, for hotels without an ethical code it was 4). On the other hand, the activity "Adoption and exercise of principles of good management" was given more importance by the managers of hotels without an ethical code (with the same median, the average rating for hotels with an ethical code was 4.39 , for hotels without one it was 5).

Seeing as the conditional median for independent hotels in 7 and the conditional median for hotel chains is 5 , it is possible to conclude that the managers of independent hotels were evaluating the activity "Long-term building of relationships with customers and suppliers" as more important. A dependency was proven for the activity "Long-term building of relationships with customers and suppliers", a greater importance was given to it by managers of smaller hotels (median for small hotels was 7, for a mid-sized hotel it is 5.5 and for a large hotel it is 5). 
The location of a hotel in the Czech Republic or Slovakia was only notable when looking at activities 2A, 2D, 2F and 2H. Czech managers found "Avoiding corruption and ethical behaviour" more important (median for Czech managers was 5, for Slovakian managers it was 4). Furthermore, "Long-term building of relationships with customers and suppliers" was evaluated as more important by Czech managers than by Slovakian (with the same median, the average rating of importance for the Czech Republic was 5.82 and for Slovakia it was 5.03). On the other hand, Slovakian managers ascribed more importance to "Respect and protection of intellectual property" (median for the Czech Republic was 2, median for Slovakia was 4) and "Respecting the rules of fair trade competition" (median for the Czech Republic was 3, median for Slovakia 4).

Table 11. P-values of the Wilcoxon* and Kruslal-Wallis** test for the influence of the existence of an ethical code and the independence and class of hotel on evaluation of the social area

\begin{tabular}{|l|l|l|l|l|l|l|}
\hline Activity & $\begin{array}{l}\text { Existence } \\
\text { of an } \\
\text { ethical } \\
\text { code* }\end{array}$ & $\begin{array}{l}\text { Hotel/hotel } \\
\text { chain* }\end{array}$ & $\begin{array}{l}\text { Hotel } \\
\text { class** }\end{array}$ & $\begin{array}{l}\text { Hotel } \\
\text { size** }\end{array}$ & $\begin{array}{l}\text { Managerial } \\
\text { position* }\end{array}$ & Region* \\
\hline $\begin{array}{l}\text { 3A) Creating conditions for } \\
\text { raising qualifications and } \\
\text { carrier growth of employees }\end{array}$ & 0,10975 & 0,68936 & 0,13056 & 0,99978 & 0,27768 & $\mathbf{0 , 0 0 0 0 1}$ \\
\hline $\begin{array}{l}\text { 3B) Elimination of } \\
\text { discriminative acts in the } \\
\text { workplace }\end{array}$ & 0,4195 & 0,82432 & 0,39271 & 0,44 & 0,28614 & $\mathbf{0 , 0 0 1 6 5}$ \\
\hline 3C) Fair reward system & $\mathbf{0 , 0 0 1 1 8}$ & 0,07859 & 0,09688 & 0,08649 & $\mathbf{0 , 0 1 2}$ & 0,69024 \\
\hline $\begin{array}{l}\text { 3D) Respect for a social } \\
\text { dialogue while preserving } \\
\text { economic stability and } \\
\text { growth }\end{array}$ & 0,84586 & 0,40862 & 0,05187 & 0,61993 & 0,96862 & 0,15722 \\
\hline $\begin{array}{l}\text { 3E) Respect for principles } \\
\text { of equal work opportunities }\end{array}$ & $\mathbf{0 , 0 0 2 3 5}$ & 0,16646 & 0,48972 & 0,70348 & 0,31506 & $\mathbf{0 , 0 0 0 0 1}$ \\
\hline $\begin{array}{l}\text { 3F) Fight against mobbing } \\
\text { and sexual harassment }\end{array}$ & 0,70928 & 0,25582 & 0,66621 & 0,43124 & $\mathbf{0 , 0 0 2 8}$ & 0,09937 \\
\hline $\begin{array}{l}\text { 3G) Emphasis on } \\
\text { humanisation of work, care } \\
\text { for the health and safety of } \\
\text { employees }\end{array}$ & $\mathbf{0 , 0 4 2 5 7}$ & 0,2775 & 0,19644 & 0,2212 & 0,67482 & 0,40572 \\
\hline $\begin{array}{l}\text { 3H) Creating a healthy } \\
\text { company culture }\end{array}$ & 0,30268 & $\mathbf{0 , 0 0 0 1 8}$ & 0,29996 & 0,0651 & 0,23091 & 0,08248 \\
\hline $\begin{array}{l}\text { 3I) Evaluating the social } \\
\text { impact of managerial } \\
\text { decisions }\end{array}$ & 0,63052 & 0,50049 & 0,09941 & 0,83128 & 0,84134 & 0,15395 \\
\hline $\begin{array}{l}\text { 3J) Adaptation of working } \\
\text { conditions for the work and } \\
\text { problem-free stay of } \\
\text { persons with health } \\
\text { disabilities }\end{array}$ & $\mathbf{0 , 0 0 3 9 7}$ & $\mathbf{0 , 0 1 8 6 1}$ & 0,46174 & 0,20952 & 0,50798 & $\mathbf{0 , 0 3 8 3 5}$ \\
\hline 3K)Company volunteering & 0,14149 & $\mathbf{0 , 0 3 8 5 9}$ & 0,40678 & 0,71669 & 0,75543 & $\mathbf{0 , 0 0 0 1 5}$ \\
\hline
\end{tabular}




\begin{tabular}{|lr|l|l|l|l|l|l|}
\hline $\begin{array}{l}\text { 3L) Organised leisure time } \\
\text { activities } \\
\text { Teambuilding }\end{array}$ & e.g. & 0,26044 & 0,22419 & 0,30239 & 0,25288 & 0,62681 & $\mathbf{0 , 0 0 0 0 9}$ \\
\hline
\end{tabular}

As the table above shows, the existence of an ethical code had an influence on the evaluation of activities 3C, 3E, 3G and 3J. Managers of hotels without an ethical code deemed most important the activities of "Fair reward system" (median for hotels with an ethical code was 8, for hotels without it was 10) and "Respect for principles of equal work opportunities" (median for hotels with an ethical code was 7, for hotels without it was 8). Managers of hotels with an ethical code ascribed more importance to "Emphasis on humanisation of work, care for the health and safety of employees" (median for hotels with an ethical code was 7.5, for hotels without it was 6) and "Adaptation of working conditions for the work and problemfree stay of persons with health disabilities" (median for hotels with an ethical code was 6 , for hotels without it was 4 ).

The independence variable influenced the opinions of respondents on activities $3 \mathrm{H}$, $3 \mathrm{~J}$ and $3 \mathrm{~K}$. "Creating a healthy company culture" was more important to managers of independent hotels (median for independent hotels was 9, for hotel chains it was 7). Managers of hotel chains deemed "Adaptation of working conditions for the work and problem-free stay of persons with health disabilities" more important (median for independent hotels was 5, for hotel chains it was 6.5), as well as "Company volunteering" (median for independent hotels was 2, for hotel chains it was 3). A connection to hotel class could not be proven amongst the answers in this area.

On the basis of the p-values in Table 11 it can be stated that the influence of hotel size on the activities in the social area could not be proven. The influence of managerial position was clear for activities 3C and 3F. "Fair reward system" was seen as more important by top managers (median for top managers was 10, for midlevel managers it was 8). "Fight against mobbing and sexual harassment" was seen as more important by mid-level managers (median for top managers was 3 , for midlevel managers it was 5).

The country in which the managers are working, had an influence on the social area of CSR when evaluating activities 3A, 3B, 3E, 3J, 3K and 3L. This area is where the responses differed most between the managers from the two countries. Managers from the Czech Republic assigned more importance to the activities "Creating conditions for raising qualifications and carrier growth of employees" (median for Czech managers was 8, for Slovakian managers it was 5), "Elimination of discriminative acts in the workplace" (median for Czech managers was 8, for Slovakian managers it was 5) and "Respect for principles of equal work opportunities" (median for Czech managers was 8, for Slovakian managers it was 5). On the other hand, managers from Slovakia see as most important the activities "Adaptation of working conditions for the work and problem-free stay of persons 
with health disabilities" (median for Czech managers was 5, for Slovakian managers it was 6), "Company volunteering" (median for Czech managers was 2, for Slovakian managers it was 5) and "Organised leisure time activities - e.g. Teambuilding" (median for Czech managers was 4, for Slovakian managers it was 7).

Table 12. P-values of the Wilcoxon* and Kruslal-Wallis** test for the influence on the evaluation of the environmental area

\begin{tabular}{|l|l|l|l|l|l|l|}
\hline Activity an & $\begin{array}{l}\text { Existence } \\
\text { of } \\
\text { ethical } \\
\text { code* }\end{array}$ & $\begin{array}{l}\text { Hotel/hote } \\
\text { chain* }\end{array}$ & $\begin{array}{l}\text { Hotel } \\
\text { class** }\end{array}$ & $\begin{array}{l}\text { Hotel } \\
\text { size** }\end{array}$ & $\begin{array}{l}\text { Manageria } \\
\text { 1 position* }\end{array}$ & Region* \\
\hline $\begin{array}{l}\text { 4A)Realisation of } \\
\text { business operations in } \\
\text { accordance with the } \\
\text { tourism development } \\
\text { plan while conserving } \\
\text { natural and cultural } \\
\text { inheritance }\end{array}$ & 0,8734 & 0,42935 & $\mathbf{0 , 0 3 9 2 9}$ & 0,32355 & $\mathbf{0 , 0 3 0 2 5}$ & $\mathbf{0 , 0 0 0 0 2}$ \\
\hline $\begin{array}{l}\text { 4B) Environmentally } \\
\text { friendly waste disposal }\end{array}$ & 0,27472 & 0,51223 & $\mathbf{0 , 0 1 3 2 6}$ & 0,88221 & $\mathbf{0 , 0 2 9 4 3}$ & $\mathbf{0 , 0 0 0 1 5}$ \\
\hline $\begin{array}{l}\text { 4C) Preservation of } \\
\text { natural resources } \\
\text { through decreased water } \\
\text { usage }\end{array}$ & 0,35997 & 0,64541 & 0,97772 & 0,1187 & 0,43755 & $\mathbf{0 , 0 4 3 9}$ \\
\hline $\begin{array}{l}\text { 4D) Use of solar panels, } \\
\text { central light switches } \\
\text { and other measures for } \\
\text { conserving electricity }\end{array}$ & $\mathbf{0 , 0 0 0 0 1}$ & 0,96282 & 0,20032 & 0,40094 & 0,09836 & $\mathbf{0 , 0 0 5 0 8}$ \\
\hline $\begin{array}{l}\text { 4E) Use of intelligent } \\
\text { systems of measuring } \\
\text { and regulation for } \\
\text { buildings organic }\end{array}$ & 0,08603 & 0,18648 & 0,83827 & 0,8584 & 0,23252 & 0,0889 \\
\hline $\begin{array}{l}\text { 4F) Choice of materials, } \\
\text { paints and other } \\
\text { components without or } \\
\text { with low amounts of } \\
\text { volatile } \\
\text { substances o, }\end{array}$ & 0,2308 & 0,79341 & 0,67001 & 0,08625 & 0,13393 & 0,26309 \\
\hline $\begin{array}{l}\text { 4G) } \\
\text { environmentally friendly } \\
\text { cleaning supplies }\end{array}$ & 0,602 & 0,28583 & 0,53846 & 0,77739 & $\mathbf{0 , 0 1 9 2 8}$ & 0,46567 \\
\hline $\begin{array}{l}\text { 4H) Decreased use of } \\
\text { chemicals of all kinds }\end{array}$ & 0,08519 & 0,37863 & 0,05651 & 0,19968 & 0,19907 & $\mathbf{0 , 0 0 2 4 1}$ \\
\hline
\end{tabular}




\begin{tabular}{|l|l|l|l|l|l|l|}
\hline $\begin{array}{l}\text { 4I) Leading customers } \\
\text { towards environmentally } \\
\text { friendly behaviour } \\
\text { (decreased water use } \\
\text { etc.) }\end{array}$ & 0,0644 & 0,59288 & 0,18474 & 0,32171 & $\mathbf{0 , 0 2 9 5 4}$ & $\mathbf{0 , 0 0 1 6}$ \\
\hline $\begin{array}{l}\text { 4J) Use of organic } \\
\text { products such as tea and } \\
\text { coffee (e.g. Fair Trade) }\end{array}$ & 0,16375 & 0,93323 & 0,08244 & 0,55831 & 0,15956 & $\mathbf{0}$ \\
\hline
\end{tabular}

Dependency on the existence of an ethical code was provable only for activity "Use of solar panels, central light switches and other measures for conserving electricity". More importance was ascribed to it by managers of hotels without an ethical code (median for hotels with an ethical code was 5, for hotels without one it is 8). Dependency on the independence of the hotel could not be proven for any of the activities.

Hotel class influenced the evaluation of activities 4A and 4B. the activity "Realisation of business operations in accordance with the tourism development plan while conserving natural and cultural inheritance" was given more importance by managers of hotels with a three-star rating (median for hotels with a 1 star rating was 4 , for a 2 star rating it was 3.5 , for a 3 star rating it was 6 , for a 4 star rating it was 5 and for a 5 star rating it was 6; however, for a 3 star rated hotel it was 6.06 as opposed to a 5.59 for a 5 star rated hotel). "Environmentally friendly waste disposal" was judging by the responses most important for managers of four-star rated hotels (median for hotels with a 1-star and a 2-star rating was 4 , for a 3 star and 5-star rating it was 7, for a 4 -star rating it was 8 ).

Based on the p-values from Table 12 there was no provable influence of hotel size on any of the activities.Influence of the managerial position held by responders was proven for activities 4A, 4B, 4G and 4I. Mid-level managers saw as most important the activity "Realisation of business operations in accordance with the tourism development plan while conserving natural and cultural inheritance" (median for mid-level managers was 8, for top managers it was 4) and activity "Environmentally friendly waste disposal" (median for mid-level managers was 8 , for top managers it was 7). Top managers assign more importance to "Use of environmentally friendly cleaning supplies" (median for mid-level managers was 5, for top managers it was 6) and to "Leading customers towards environmentally friendly behaviour" (median for mid-level managers was 5, for top managers it was 7).

Likewise, when evaluating the environmental area, the most common influencing factor on the responses was the region in which the hotel is located. Dependency could be proven in the judgement of activities $4 \mathrm{~A}, 4 \mathrm{~B}, 4 \mathrm{C}, 4 \mathrm{D}, 4 \mathrm{H}, 4 \mathrm{I}$ a $4 \mathrm{~J}$. Managers from the Czech Republic pay more attention to the activity "Realisation of business operations in accordance with the tourism development plan while conserving natural and cultural inheritance" (median for Czech managers was 6, for 
Slovakian managers it was 3), activity "Environmentally friendly waste disposal" (median for Czech managers was 8, for Slovakian managers it was 6), activity "Preservation of natural resources through decreased water usage" (median for Czech managers was 7, for Slovakian managers it was 6) and activity "Use of solar panels, central light switches and other measures for conserving electricity" (median for Czech managers was 6, for Slovakian managers it was 3).

For Slovakian managers, a greater importance is attributed to the activity "Decreased use of chemicals of all kinds" (median for Czech managers was 4, for Slovakian managers it was 6.5), "Leading customers towards environmentally friendly behaviour" (median for Czech managers was 5, for Slovakian managers it was 7.5) and activity "Use of organic products such as tea and coffee" (median for Czech managers was 3, for Slovakian managers it was 8).

\section{Conclusion}

This study broadens the perspective and analyses management views on the importance of selected four areas of the Corporate Social Responsibility in hotel industry in the Czech Republic. It links to previous Czech studies of hospitality industry by Čech and Neubauer (2010) and Jindrichovska and Kohout (2016).

If the potential of corporate social responsibility is to be fully achieved, it cannot become solely the privilege of large companies, but rather it must be incorporated by the whole corporate sector, including the hotel industry. In the Czech Republic and Slovakia, many small and mid-sized companies are acting in socially responsible ways, even if they mostly employ more informal and Personal approach than large companies and their actions stem mostly from managerial intuition. Very often, it is the representatives of this group of companies which thanks to their deep understanding of problems of their employees, customers and local community make a lot better decision. Because they are closer to communities in which they actively perform. Companies, which do not act in such manner can in no way expect that their shareholders will ignore this and will continuously support them.

Managers of hotels and hotel chains should align their views to the idea, that in the current intensely competitive environment it is no longer enough to just compete in the quality of offered services. Now, the good name of hotel or hotel chain and its trustworthiness of its brand, which offers said services. To gain a good reputation, regardless of the area in which the company operates, it is important to offer quality services and products but also build a solid brand. Raising the reputation of the company enables the unit to distinguish oneself from the other companies on the market, and to gain customers who disapprove of wasting resources and to reach out to customers who are interested in environmental sustainability and harmony in society. Another opportunity can be gained by attracting socially conscious suppliers or in the personnel area, where this might attract young, talented employees who find social values as important factor. 
Based on the research, it can be said that the overall lowest importance in the area of relevant community involvement was attributed to "Financial support for local culture and social traditions". The remaining activities were ranked as almost similarly important. Respondents thus prefer activities, which will vicariously bring them a larger profit and are less likely to prefer increased expenses by offering financial support. By testing hypotheses, it has been found that the influence of the chosen factors on the evaluation of importance of the individual factors was proven for the activity "Preparation of local foods" to which more importance was attributed by managers of five-star rated hotels and managers of mid-sized hotels. Mid-level managers attributed more importance to the activity "Offering information about local sights and natural curiosities".

In the economic perspective the "Long-term building of relationships with customers and suppliers" was attributed most importance, followed by "Innovation and continuous development of the hotel/hotel chain". The lowest importance was assigned to "Respect and protection of intellectual property" and "Respecting the rules of fair trade competition". In this area there was a significant influence of the existence of an ethical code of examined hotels on the activities "Avoiding corruption and ethical behaviour" and "Trustworthy, transparent business transactions and provision of information about the company". In contrary, activity "Adoption and exercise of principles of good management" was given more importance by managers of hotels without ethical code. Managers of independent hotels, managers of small hotels and Czech managers assigned more importance to "Long-term building of relationships with customers and suppliers". Czech managers saw "Avoiding corruption and ethical behaviour" as more important while Slovakian managers assigned more importance to "Respect and protection of intellectual property" and "Respecting the rules of fair trade competition".

In the social perspective the overall highest importance was given to "Creating conditions for raising qualifications and carrier growth of employees" and furthermore to "Fair reward system". The lowest importance was assigned to "Company volunteering" and "Fight against mobbing and sexual harassment". Managers of hotels of hotels with an ethical code saw as more important the activity "Emphasis on humanisation of work, care for the health and safety of employees" and "Adaptation of working conditions for the work and problem-free stay of persons with health disabilities". On the opposite side the managers of hotels without an ethical code assigned more importance to "Fair reward system" and "Respect for principles of equal work opportunities". For managers of independent hotels more importance was attributed to the activity "Creating a healthy company culture". For managers of hotel chains, "Adaptation of working conditions for work and problemfree stay of persons with health disabilities" and "Company volunteering" was more important. "Fair reward system" was seen as more important by top managers. "Fight against mobbing and sexual harassment" was seen as more important by midlevel managers. Czech managers rated "Creating conditions for raising qualifications and carrier growth of employees" as more important, as well as "Elimination of 
discriminative acts in the workplace" and "Respect for principles of equal work opportunities". For Slovak managers, the activities "Adaptation of working conditions for the work and problem-free stay of persons with health disabilities", "Company volunteering" and "Organised leisure time activities - e.g. Teambuilding" were more important.

The CSR can bring benefits to the company only when it is prepared and realized through meaningful and trustworthy projects. The trustworthiness of socially responsible activities is helped by their personalisation, originality and personal engagement as well as the conviction, that these activities are mean completely seriously. Society expects socially responsible behaviour from all companies. Companies in the hotel industry are therefore aware, that the best marketing results arise from fulfilling the needs of the customer in such a way that will make them use their dining and accommodation services again and give good references to their acquaintances.

In the environmental perspective the highest score was given to "Environmentally friendly waste disposal", followed by "Preservation of natural resources through decreased water usage". On the other hand, the lowest importance was given to the "Use of organic products such as tea and coffee (e.g. Fair Trade)" and "Choice of materials, paints and other components without or with low amounts of volatile organic substances". Managers of hotels without an ethical code assigned more importance to" Use of solar panels, central light switches and other measures for conserving electricity". Managers of three-star rated hotels saw as more important the activity "Realisation of business operations in accordance with the tourism development plan while conserving natural and cultural inheritance”.

"Environmentally friendly waste disposal" was according to the research seen as more important for managers of four-star hotels. Mid-level managers claimed as more important the activities "Realisation of business operations in accordance with the tourism development plan while conserving natural and cultural inheritance" and "Environmentally friendly waste disposal". Top managers assign more importance to "Use of environmentally friendly cleaning supplies" and "Leading customers towards environmentally friendly behaviour". Czech managers claimed, "Realisation of business operations in accordance with the tourism development plan while conserving natural and cultural inheritance", "Environmentally friendly waste disposal", "Preservation of natural resources through decreased water usage" and" Use of solar panels, central light switches and other measures for conserving electricity" to be more important. Slovakian managers saw more importance in "Decreased use of chemicals of all kinds, "Leading customers towards environmentally friendly behaviour" and activity "Use of organic products such as tea and coffee".

Further recommendations for the next research arebroad. However, the authors are going to explore how the company can expand by achieving the highest reputation in 
the field of the CSR.By implementing one or a combination of multiple social initiatives (Cause Promotion, Cause-Related Marketing, Social Marketing, Corporate Philanthropy, Volunteer Work, Corporate Social Responsibility Practices), can a company gain and maintain an outstanding reputation in the field of CSR. Many customers currently expect and appreciate that the company is and want to be socially committed in the future, is more interested in environmental issues and reflects the values of its customers and stakeholders (Kotler et al., 2012).

\section{References:}

Andel, J. 2003. Statistic methods. Praha, Matfyz press.

Baldacchino, J.P., Camilleri, C., Grima, S. and Bezzina, H.F. 2017. Assessing Incentive and Monitoring Schemes in the Corporate Governance of Maltese Co-operatives. European Research Studies Journal, 20(3A), 177-195.

Cech, P. and Neubauer, J. 2016. Strategy of Growth and Corporate Responsibility. Logos Polytechnikos 7(3), 59-76.

Demsar, J. 2006. Statistical comparisons of classifiers over multiple data sets. Journal of Machine Learning Research, 7, 1-30.

Devore, L.D. 2012. Probability and Statistics for Engineering and the Sciences, 8th ed., Brooks/Cole, Cengage Learning.

EUR-Lex. 2011.Communication the Commission to the European Parliament, the Council, the European Economic and Social Committee and the Committee of the Regions A renewed EU strategy 2011-14 for Corporate Social Responsibility, http://eurlex.europa.eu/legal-content/EN/TXT/?uri=CELEX\%3A52011DC0681.

European Commission. 2001. Green Paper: Promoting a European Framework for Corporate Social Responsibility, http://europa.eu.int/eurlex/en/com/gpr/2001/com2001_0366en01.pdf.

Giannakopoulou, N.E., Stamatopoulos, V.T. and Thalassinos, I.E. 2016. Corporate governance in shipping: An overview. Maritime Policy and Management, 43(1), 1938.

Haski-Leventhal, D., Roza, L., Meijs, C.L. 2017. Congruence in Corporate Social Responsibility: Connecting the Identity and Behaviour of Employers and Employees. Journal of Business Ethics, 143(1), 35-51.

Ivanova, I.A. and Bikeeva, M.V. 2016. Corporate Social Responsibility: Specificity, Formation Mechanism, Estimation of Management Efficiency. European Research Studies, 19(3A), 167-184.

Jindrichovska, I. and Kohout, M. 2016. Information System in Czech Hotels: Introductory Study, in Radka Balakovska. Sbornik from the International Scientific Conference Hotel, Tourism and Education, Prague: Vysoká škola hotelova v Praze 8, 55-63.

Kim, H.L., Rhou, Y., Uysal, M. and Kwon, N. 2017. An examination of the links between corporate social responsibility (CSR) and its internal consequences. International Journal of Hospitality Management, 26-34.

Kotler, P., Hessekiel, D., Lee, N.R. 2012. Good Works! Marketing and Corporate Initiatives that Build a Better World... and the Bottom Line. John Wiley and Sons, New York.

McWilliams, A. and Siegel, D. 2001. Corporate social responsibility: A theory of the firm perspective. Academy of Management Review, 26, 117-127.

McWilliams, A., Siegel, D.S. and Wright, P.M. 2006. Corporate social responsibility: Strategic implications. Journal of Management Studies, 43(1), 1-18. 
Misani, N. 2010. The convergence of corporate social responsibility practices. Management Research Review, 33(7), 734-748.

Pavlik, M., Belcik, M, 2010. The organization's corporate responsibility. CSR in practice and how they gave them. Prague, Grada Publishing.

Quad, X., Heoand, C.Y., Lee, S. 2017. How do consumers' perceptions differ across dimensions of corporate social responsibility and hotel types? Journal of Travel \& Tourism Marketing, 34.

R Core Team. 2017. R: A language and environment for statistical computing. R Foundation for Statistical Computing, https://www.R-project.org/.

Rupeika-Apoga, R., Solovjova, I. 2017. Access to Finance for Latvian SMEs. European Research Studies Journal, 20(3A), 57-68.

Savina, N.T. 2016. The Institutionalization of the Concept of Corporate Social Responsibility: Opportunities and Prospects. European Research Studies Journal, 19(3) Part B, 56-76.

Sharifz, K., Mullakhmetov, N.F., Sadriev, D.R. and Akhmetshin, M.E. 2018. Corporate Culture in Management Systems. European Research Studies Journal, 21(1), 519-528.

Skacelik, P. 2010. Society Responsibility of the Organization. JENA, Sumperk.

Suryanto, T., Thalassinos, E.J., Thalassinos, I.E. 2017. Board Characteristics, Audit Committee and Audit Quality: The Case of Indonesia. International Journal of Economics \& Business Administration, 5(3), 47-57.

Theodoulidis, B., Diaz, D., Crotto, F. and Rancati, E. 2017. Exploring corporate social responsibility and financial performance through stakeholder theory in the tourism industries. Tourism Management, 62, 173-188.

Tian, Q. and Robertson, J.L. 2018. How and When Does Perceived CSR Affect Employees' Engagement in Voluntary Pro-environmental Behavior? Journal of Business Ethics, 1-14.

Vallee, G. 2005. What is corporate social responsibility? The case of Canada. Managerial Law, 47(5), 20-46.

Veber, J. 2014. Management: fundamentals, modern management approaches, performance and prosperity. Prague, Management Press.

Veber, J., Srpova, J. 2012. Entrepreneurship for male and middle businesses. Prague, Grada Publishing.

Yaoqi, L., Fang, S. and Chuan, T.Ch. 2017. Consumer response to discontinuation of corporate social responsibility activities of hotels. International Journal of Hospitality Management, 64, 41-50. 